\title{
Development of a loop-mediated isothermal amplification method for diagnosing Pneumocystis pneumonia
}

\author{
Natsu Uemura, ${ }^{1,2}$ Koichi Makimura, ${ }^{1}$ Masanobu Onozaki, ${ }^{3}$ \\ Yoshihito Otsuka, ${ }^{4}$ Yasuhiro Shibuya, ${ }^{5}$ Hirohisa Yazaki, ${ }^{6}$ Yoshimi Kikuchi, ${ }^{6}$ \\ Shigeru $\mathrm{Abe}^{1}$ and Shoji Kudoh ${ }^{2}$ \\ ${ }^{1}$ Teikyo University Institute of Medical Mycology, 539 Otsuka, Hachioji, Tokyo 192-0395, Japan \\ ${ }^{2}$ Department of Pulmonary Medicine/Infection and Oncology, Nippon Medical School, Tokyo, Japan \\ ${ }^{3}$ Kanto Chemical Co. Inc., Tokyo, Japan \\ ${ }^{4}$ Social Insurance Central General Hospital, Tokyo, Japan \\ ${ }^{5}$ Tokyo Metropolitan Hiroo General Hospital, Tokyo, Japan \\ ${ }^{6}$ AIDS Clinical Center, International Medical Center of Japan, Tokyo, Japan
}

Correspondence

Natsu Uemura

s3016@nms.ac.jp

Received 7 February 2007

Accepted 13 September 2007

\begin{abstract}
Loop-mediated isothermal amplification (LAMP) is a novel, rapid nucleic acid amplification method with high specificity and sensitivity under isothermal conditions. In this study a LAMP assay for diagnosing Pneumocystis pneumonia (PCP) was developed. Oligonucleotide primers specific for Pneumocystis species were designed corresponding to 18S rRNA gene sequences. The assay, performed for $30 \mathrm{~min}$ at $61{ }^{\circ} \mathrm{C}$, was capable of detecting 50 copies per tube $\left(2 \times 10^{3}\right.$ copies $\mathrm{ml}^{-1}$ ) in $30 \mathrm{~min}$ and did not show cross-reactivity to other species of fungi, including the genera Candida, Aspergillus and Cryptococcus. A total of 21 of 24 clinical specimens (sputum and bronchoalveolar lavage fluid) from patients with suspected PCP tested positive using the LAMP assay by real-time fluorescence detection. The results of the LAMP reaction were also observed by real-time turbidity detection and end-point visual turbidity or fluorescence detection. With real-time fluorescence detection, melting curves of the products were effective at distinguishing specific amplification from non-specific amplification or self-amplification. Visual detection was also possible as a rapid and easy assay using only a heat block and a black light.
\end{abstract}

\section{INTRODUCTION}

Pneumocystis is a fungus belonging to the class Archiascomycetes, phylum Ascomycota. The human pathogen was known as Pneumocystis carinii f. sp. hominis, but has been renamed Pneumocystis jirovecii based on the results of molecular biological studies (Frenkel, 1999; Stringer et al., 2002). This opportunistic fungus causes Pneumocystis pneumonia (PCP) in patients infected with human immunodeficiency virus (HIV), as well as other immunocompromised patients. Recently, human-tohuman transmission (Helweg-Larsen et al., 1998; Hocker et al., 2005) and colonization by $P$. jirovecii have been reported in the general population (Medrano et al., 2005). Although the standard method for diagnosis of PCP is

Abbreviations: BALF, bronchoalveolar lavage fluid; BLF, bronchial lavage fluid; HIV, human immunodeficiency virus; LAMP, loop-mediated isothermal amplification; PCP, Pneumocystis pneumonia.

The GenBank/EMBL/DDBJ accession number for the 18S rRNA gene sequence of Pneumocystis jirovecii reported in this paper is AB266392. based on microscopic examination of clinical specimens [bronchoalveolar lavage fluid (BALF), sputum or lung biopsy], the sensitivity of this method is poor except in the hands of highly skilled examiners (Flori et al., 2004). Therefore, PCR-based methods are widely used in Japan for the diagnosis of Pneumocystis infection. However, conventional PCR methods require a thermal cycler and electrophoresis for detection, whilst real-time PCR allows simultaneous amplification and detection, but requires expensive equipment and therefore is not available in general clinical laboratories.

Recently, a new specific DNA amplification technique called loop-mediated isothermal amplification (LAMP) was developed (Nagamine et al., 2002; Notomi et al., 2000), and has already been applied to the detection of pathogenic viruses (Poon et al., 2005), bacteria (Iwamoto et al., 2003), parasites (Poon et al., 2006) and fungi (Endo et al., 2004). LAMP, which does not involve the use of PCR, allows the rapid amplification of DNA with high specificity under isothermal conditions using DNA polymerase with 
strand-displacement activity. Specific nucleotide extension is achieved with four primers recognizing six distinct regions on the target. The amplification time can be further shortened by using an additional two primers, termed the loop primers (Nagamine et al., 2002). Moreover, LAMP products can be detected not only using specialized equipment but also by visual observation of turbidity or fluorescence (Mori et al., 2001). Here, we report the development of a Pneumocystis-specific LAMP assay, which has been applied successfully to clinical specimens for diagnosis of PCP.

\section{METHODS}

Fungal strains. A total of 69 strains from 51 species of fungi were used as controls in the present study (Table 1).

Preparation of DNA from fungal cells. With the exception of $P$. jirovecii, all fungal strains were grown on Sabouraud dextrose agar [1\%(w/v) peptone; $1 \%(\mathrm{w} / \mathrm{v})$ glucose; $1.5 \%(\mathrm{w} / \mathrm{v})$ agar] at 27 or $37{ }^{\circ} \mathrm{C}$ for $1-5$ days. Rapid preparation of DNA from the fungi was performed by a modification (Makimura et al., 1994) of a method described by Cenis (1992). Briefly, small samples of mycelia grown on Sabouraud dextrose agar were placed in lysis buffer [200 mM Tris/ $\mathrm{HCl}(\mathrm{pH} \mathrm{8.0)}, 0.5 \%$ (w/v) SDS, $250 \mathrm{mM} \mathrm{NaCl}, 25 \mathrm{mM}$ EDTA] and crushed with a conical grinder. These samples were incubated at $100{ }^{\circ} \mathrm{C}$ for $15 \mathrm{~min}$, mixed with $150 \mu \mathrm{l} 3.0 \mathrm{M}$ sodium acetate, kept at $-20{ }^{\circ} \mathrm{C}$ for $10 \mathrm{~min}$ and then centrifuged at $10000 \mathrm{~g}$ for $5 \mathrm{~min}$. The supernatants were extracted once with phenol/chloroform/isoamyl alcohol $(25: 24: 1$, by vol.) and once with chloroform. DNA was precipitated with an equal volume of 2-propanol at $-20{ }^{\circ} \mathrm{C}$ for $10 \mathrm{~min}$, washed with $0.5 \mathrm{ml} 99 \%$ ethanol, dried and resuspended in $50 \mu \mathrm{l}$ ultrapure water (MilliQ Synthesis A10; Millipore). Aliquots of $1 \mu \mathrm{l}$ of the resulting solutions were used as templates for PCR.

DNA from yeasts was prepared by a modification of the method described by Makimura et al. (1994). Briefly, small samples of individual yeast colonies were suspended in $100 \mu$ lysis buffer. The samples were mixed using a vortex for $5 \mathrm{~s}$ and incubated at $100{ }^{\circ} \mathrm{C}$ for $15 \mathrm{~min}$. Next, $100 \mu \mathrm{l} 3.0 \mathrm{M}$ sodium acetate was added and the preparations were mixed. After incubation at $-20{ }^{\circ} \mathrm{C}$ for $10 \mathrm{~min}$, the samples were centrifuged at $10000 \mathrm{~g}$ for $5 \mathrm{~min}$, after which the supernatants were transferred to fresh tubes. DNA was precipitated with an equal volume of 2-propanol, washed with $0.5 \mathrm{ml} 99 \%$ ethanol, dried and resuspended in $100 \mu$ ultrapure water.

Clinical specimens. A total of 38 clinical specimens ( 24 from PCP and 14 from non-PCP patients) were examined. Twenty-four specimens, comprising eight sputum samples and sixteen BALF samples, were collected from twenty-one patients diagnosed with PCP and admitted to three hospitals in Tokyo (Social Insurance Central General Hospital, Tokyo Metropolitan Hiroo Hospital or the International Medical Center of Japan) between January 1998 and July 2006. In the PCP group (Table 2), PCP was diagnosed by microscopic examination, or symptoms were improved by PCP therapy (co-trimoxazole, i.e. sulfamethoxazole/trimethoprim and/or pentamidine isethionate). In addition, 1 BALF sample and 13 bronchial lavage fluid (BLF) samples were collected from the 14 non-PCP patients (Table 3). The subjects in the non-PCP group, which comprised 1 patient with idiopathic pulmonary fibrosis and 13 with lung cancer, did not have fever or inflammatory signs. The PCP group included six patients with collagen disease (rheumatoid arthritis) treated with steroids or immunosuppressive agents, and one lung cancer patient treated with chemotherapy. The patients in the non-PCP group received no treatment with anti-Pneumocystis agents.

DNA preparation from clinical specimens. Clinical specimens were stored at $-80{ }^{\circ} \mathrm{C}$ before DNA extraction using a NucliSENS kit manually with MiniMAG (bioMérieux) in accordance with the manufacturer's instructions. Samples of 200-1000 $\mu$ l sputum, BALF or BLF were used for extraction and sample DNA was stocked at $-80{ }^{\circ} \mathrm{C}$ before use.

Primer design. Oligonucleotide primers specific for the genus Pneumocystis were designed corresponding to regions of the $18 \mathrm{~S}$ rRNA genes of $P$. jirovecii reported by Shah et al. (1996) and to genomic sequences determined in our laboratory. The following Archiascomycetes, Hemiascomycetes and human sequences were also used as references: P. carinii (host, ferret; GenBank accession no. S83267), P. carinii (host, rat; L27658), Pneumocystis murina (AY532651), P. carinii (X12708), Taphrina carnea (AB000948), Taphrina virginica (AB000960), Taphrina robinsoniana (AB000958), Taphrina nana (AB000955), Taphrina wiesneri (D12531), Taphrina communis (AB000949), Taphrina ulmi (AB000959), Schizosaccharomyces pombe (X58056), Candida albicans (E15168), Saccharomyces cerevisiae (Z75578) and Homo sapiens (M10098). Sequences were analysed using GENETYX software (Genetyx).

The sequences of our newly designed oligonucleotide PCR primers

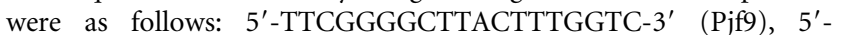
GTAGTTAGTCTTCAATAAATCT-3' (Pjr4), 5'-AGGCCTACCATGGTTTCG-3' (Pjf8) and 5'-CTTCGGAGGACCGGGCCGT-3' (Pjr8). In addition to these primers, the 18S rRNA gene-based universal fungal primers NS1, NS3, NS5, NS4, NS6 and NS8 (White et al., 1990) were also used for nested PCR and sequencing as shown in Fig. 1.

As LAMP primers, a set of six oligonucleotides comprising two outer (F3 and B3), two inner (FIP and BIP) and two loop primers (FL and $\mathrm{BL})$ recognizing eight distinct regions on the target sequence were designed using LAMP primer design support software (Primer Explorer version 3.0; Eiken Genome; http://primerexplorer.jp/). The FIP primer consisted of F2 and the complementary strand of F1 (F1c). The BIP primer consisted of B2 and the complementary strand of B1 (B1c). The sequences and positions of these primers are shown in Table 4 and Fig. 1. All oligonucleotides were synthesized by Sigma-Aldrich.

PCR and plasmid preparation. Nested PCR was performed to amplify part of the $18 \mathrm{~S}$ rRNA gene using primers NS1, NS8, Pjf9 and Pjr4. Each PCR mixture contained $10 \mu 10 \times$ reaction buffer (GE Healthcare Bio-Sciences), $200 \mu \mathrm{M}$ each dATP, dCTP, dGTP and dTTP (Toyobo), 2.5 U Taq polymerase (GE Healthcare Bio-Sciences), $30 \mathrm{pmol}$ each primer and $1 \mu \mathrm{l}$ DNA template solution. Ultrapure water was added to a final volume of $100 \mu$ l. First-round PCR was performed with primers NS1 and NS8 under the following conditions: $94{ }^{\circ} \mathrm{C}$ for $4 \mathrm{~min}$; 30 cycles of $94{ }^{\circ} \mathrm{C}$ for $1 \mathrm{~min}, 55{ }^{\circ} \mathrm{C}$ for $2 \mathrm{~min}$ and $72{ }^{\circ} \mathrm{C}$ for $1.5 \mathrm{~min}$; and $72{ }^{\circ} \mathrm{C}$ for $10 \mathrm{~min}$. Secondround PCR was performed with primers Pjf9 and Pjr4 under the following conditions: $94{ }^{\circ} \mathrm{C}$ for $4 \mathrm{~min} ; 25$ cycles of $94{ }^{\circ} \mathrm{C}$ for $1 \mathrm{~min}$, $60{ }^{\circ} \mathrm{C}$ for $15 \mathrm{~s}$ and $72{ }^{\circ} \mathrm{C}$ for $15 \mathrm{~s}$; and $72{ }^{\circ} \mathrm{C}$ for $10 \mathrm{~min}$. PCR products were separated by electrophoresis on $1.2 \%$ agarose gels, stained with ethidium bromide and visualized by UV irradiation.

The PCR product amplified with the Pjf9 and Pjr4 primers was ligated into the TA cloning vector pCR 2.1 (Original TA cloning kit; Invitrogen). The ligated product was introduced into Escherichia coli DH $5 \alpha$ (Nippon Gene) by transformation. After propagation and purification of the plasmid, the concentration (copies $\mu l^{-1}$ ) was calculated from the measurement of $A_{260}$ and the molecular mass of the plasmid. 
Table 1. Fungal species and strains used in the LAMP assay to determine specificity

\begin{tabular}{|c|c|}
\hline Species & Strain \\
\hline Candida albicans & $\begin{array}{l}\text { ATCC 10231, TIMM 1768, } \\
\text { TIMM } 1308\end{array}$ \\
\hline Candida glabrata & ATCC 90030, CBS 138 \\
\hline Candida krusei & TIMM 3404, ATCC 6258 \\
\hline Candida dubliniensis & CBS 7987, CBS8500 \\
\hline Candida tropicalis & ATCC 750, Lucy colony S 9/1 \\
\hline Candida parapsilosis & ATCC 90018, ATCC 22019 \\
\hline Candida guilliermondii & TIMM 0257, TIMM 3400 \\
\hline Clavispora lusitaniae & JCM 1610, TIMM 4124 \\
\hline Saccharomyces cerevisiae & ATCC 9763 \\
\hline Schizosaccharomyces pombe & L972h- \\
\hline Geotrichum candidum & TIMM 0693 \\
\hline Cryptococcus gattii & CN 03010907, CN 03010906 \\
\hline Cryptococcus neoformans & ATCC 90113, CN 03010904 \\
\hline Pichia anomala & TIMM 3420, TIMM 3826 \\
\hline Trichosporon asahii & CBS 2497, 1/26 No.43 \\
\hline Aspergillus fumigatus & TIMM 0108, TIMM 1776 \\
\hline $\begin{array}{l}\text { Aspergillus fumigatus var. } \\
\text { fumigatus }\end{array}$ & JCM 10253 \\
\hline Aspergillus niger & $\begin{array}{l}\text { JCM 10254, TIMM 0114, } \\
\text { TIMM } 0115\end{array}$ \\
\hline Aspergillus flavus & $\begin{array}{l}\text { JCM 2061, TIMM 0057, } \\
\text { TIMM } 0059\end{array}$ \\
\hline Aspergillus conicus & JCM 1725 \\
\hline Aspergillus restrictus & JCM 1727 \\
\hline Aspergillus ustus & JCM 1928 \\
\hline Aspergillus sclerotiorum & JCM 1962 \\
\hline Aspergillus unguis & JCM 2256 \\
\hline Aspergillus tamarii & JCM 2259 \\
\hline Aspergillus avenaceus & JCM 2719 \\
\hline Aspergillus sydowii & JCM 2722 \\
\hline Aspergillus nidulans var. nidulans & JCM 2728 \\
\hline Aspergillus varians & JCM 2760 \\
\hline Aspergillus clavatus & JCM 10080 \\
\hline Aspergillus oryzae & JCM 10114 \\
\hline Aspergillus clavatonanicus & JCM 10183 \\
\hline Aspergillus candidus & JCM 10250 \\
\hline Aspergillus ochraceus & JCM 10255 \\
\hline Aspergillus penicillioides & JCM 10256 \\
\hline Aspergillus terreus var. terreus & JCM 10257 \\
\hline Aspergillus versicolor & JCM 10258 \\
\hline Eurotium amstelodami & JCM 1565 \\
\hline Eurotium chevalieri & JCM 1568 \\
\hline Eurotium herbariorum & JCM 1575 \\
\hline Neosartorya fischeri var. fischeri & JCM 1740 \\
\hline Neosartorya quadricincta & JCM 1855 \\
\hline Petromyces alliaceus & JCM 1948 \\
\hline Emericella rugulosa & JCM 2729 \\
\hline Fennellia nivea & JCM 2731 \\
\hline Penicillium marneffei & TIMM 4090 \\
\hline Penicillium expansum & TIMM 1293 \\
\hline Pseudallescheria boydii & TIMM 0886 \\
\hline Rhizopus oryzae & TIMM 0921 \\
\hline Mucor circinelloides & TIMM 3177 \\
\hline Fusarium moniliforme & TIMM 1294 \\
\hline
\end{tabular}

For nested PCR to detect $P$. jirovecii from clinical specimens, we used the Pneumocystis-specific primers Pjf9 and Pjr4 for first-round PCR and Pjf8 and Pjr8 for second-round PCR. The other PCR components were as described above. Both first- and second-round PCRs were performed under the following conditions: $94{ }^{\circ} \mathrm{C}$ for $4 \mathrm{~min}$; 30 cycles of $94{ }^{\circ} \mathrm{C}$ for $1 \mathrm{~min}, 55{ }^{\circ} \mathrm{C}$ for $2 \mathrm{~min}$ and $72{ }^{\circ} \mathrm{C}$ for $1.5 \mathrm{~min}$; and $72{ }^{\circ} \mathrm{C}$ for $10 \mathrm{~min}$.

$18 S$ rRNA gene sequencing. The $18 \mathrm{~S}$ rRNA gene DNA extracted from clinical sample number 1 (PCP group) was sequenced. Fig. 1 shows the location of the primers on the 18S rRNA gene. Both strands of the primary PCR product (generated with primers NS1 and NS8) were sequenced directly using an ABI PRISM BigDye terminator v1.1 cycle sequencing kit; Applied Biosystems) using primers NS1, NS3, NS4, NS5, NS6 and NS8 as reported by White et al. (1990) and an automated sequencer (ABI PRISM 310 genetic analyser; Applied Biosystems), in accordance with the manufacturer's instructions.

LAMP assay. The LAMP reaction was performed with a Loopamp DNA amplification kit (Eiken Chemical) in reaction mixtures composed of 40 pmol each of primers FIP and BIP, 5 pmol each of primers $\mathrm{F} 3$ and $\mathrm{B} 3,20$ pmol each of primers FL and BL, $12.5 \mu \mathrm{l} 2 \times$ reaction mixture, $1 \mu \mathrm{l}$ Bst DNA polymerase, $2 \mu \mathrm{l}$ DNA sample and distilled water up to a final volume of $25 \mu$ l. The mixtures were incubated at $61{ }^{\circ} \mathrm{C}$ for $30 \mathrm{~min}$ (Realoop-30; Eiken Chemical) or 60 min (LightCycler V3; Roche Diagnostics), and then heated at $80{ }^{\circ} \mathrm{C}$ for $2 \mathrm{~min}$ to terminate the reaction. When using the LightCycler, $20 \mathrm{mU}$ Tth pyrophosphatase $\mathrm{ml}^{-1}$ (thermostable; Roche Diagnostics) and $0.25 \mu \mathrm{g}$ YO-PRO1 $\mathrm{ml}^{-1}$ (a propidium dye; Molecular Probes) were added to the reaction mixtures. The temperature transition rate was $0.2{ }^{\circ} \mathrm{C} \mathrm{s}^{-1}$, increasing from 60 to $98{ }^{\circ} \mathrm{C}$, and the cooling temperature was $30{ }^{\circ} \mathrm{C}$ for $1 \mathrm{~min}$ for melting curve analysis. For visual fluorescence detection, $1 \mu$ fluorescent detection reagent (Eiken Chemical) was added to the reaction mixture. Control samples of plasmid solution $\left(10^{2}, 10^{4}\right.$ and $10^{6}$ copies per tube, i.e. $4 \times 10^{3}, 4 \times 10^{5}$ and $4 \times 10^{7}$ copies $\mathrm{ml}^{-1}$, respectively) were checked each time.

Detection of LAMP products. LAMP products were detected by real-time fluorescence detection with a LightCycler, real-time turbidity detection with a Realoop-30, and end-point turbidity or visual fluorescence detection, the latter being judged under UV irradiation. When using the LightCycler, melting curves of the products were analysed and specific reactions were identified.

Sensitivity and specificity of the LAMP assay. The sensitivity of the LAMP assay was examined using serial dilutions of plasmid solution $\left(1,10,10^{2}, 10^{3}, 10^{4}\right.$ and $2 \times 10^{6}$ copies per tube, i.e. 40, $4 \times 10^{2}, 4 \times 10^{3}, 4 \times 10^{4}, 4 \times 10^{5}$ and $8 \times 10^{7}$ copies $\mathrm{ml}^{-1}$, respectively) with triplicate samples. Specificity was examined for 51 fungal species (69 strains), as shown in Table 1.

\section{RESULTS AND DISCUSSION}

\section{Specificity}

A plasmid construct containing the nucleotide sequence of the 18S rRNA gene of $P$. jirovecii (GenBank accession no. AB266392) was amplified by the LAMP method. The experiment using LAMP primers for $P$. jirovecii did not show cross-reactivity with pathogenic or environmental fungi. DNA samples extracted from 69 strains of 51 species of fungi shown in Table 1, including the genera Candida, 
Table 2. Clinical information on specimens collected from PCP patients

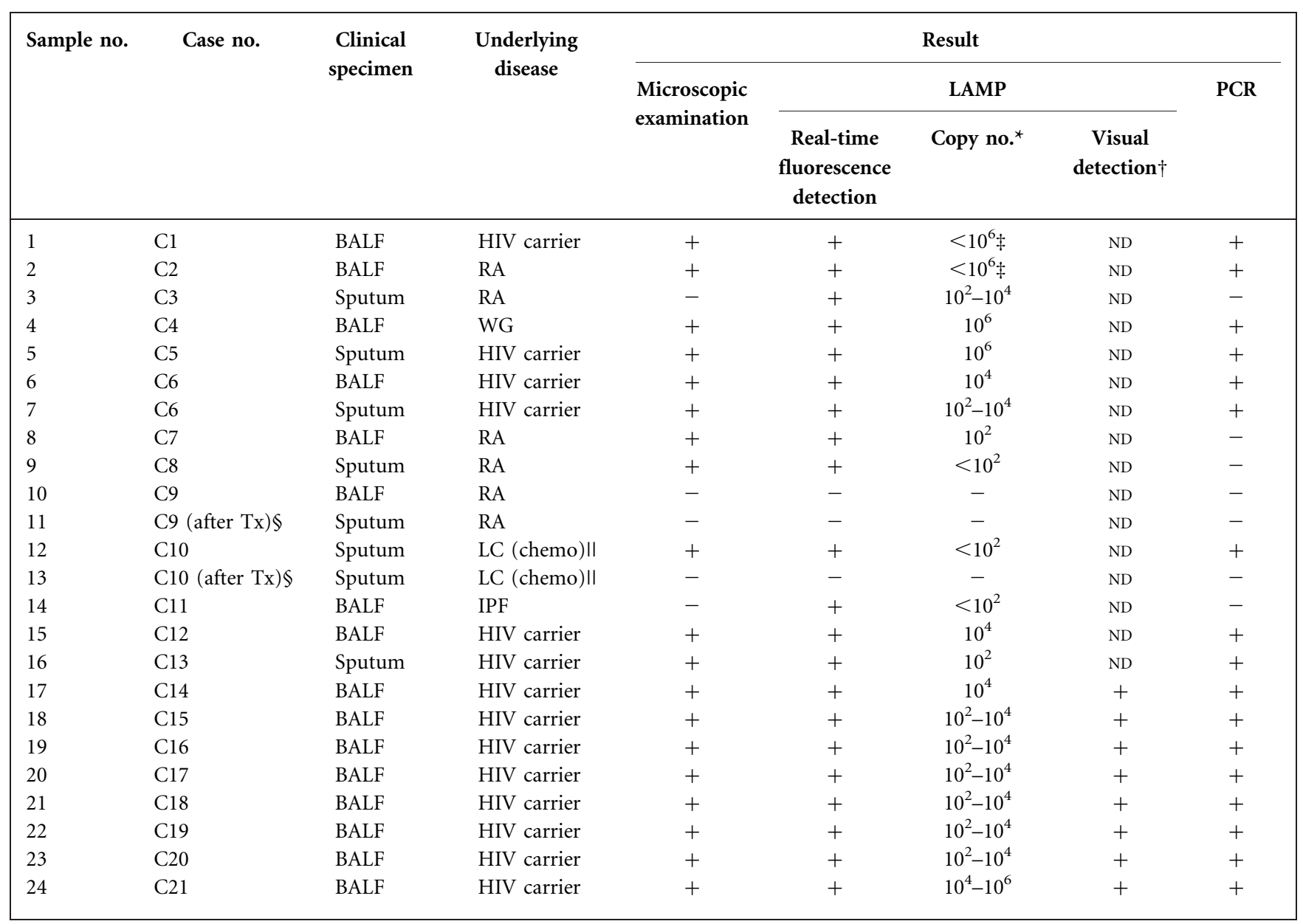

IPF, Idiopathic pulmonary fibrosis; LC, lung cancer; ND, not determined; RA, rheumatic arthritis; WG, Wegener's granulomatosis.

${ }^{*}$ When clinical specimens were examined by LAMP assay with the LightCycler, $10^{6}, 10^{4}$ and $10^{2}$ DNA copies of $P$. jirovecii plasmid were included together. The estimate of copy number for each sample is based on these amplification curves.

$\dagger$ Visual detection was by end-point visual turbidity and fluorescence detection. Both methods gave identical results. ND indicates that experiments to check visual detection could not be done as the amount of clinical specimen was too small.

$¥$ As the amount of clinical specimens was small, experiments to check quantitative capability could not be performed.

§After PCP therapy.

IIUndergoing chemotherapy.

Aspergillus and Cryptococcus, were not detected by the LAMP method.

\section{Sensitivity}

With a LAMP assay specific for Pneumocystis, it was possible specifically to detect Pneumocystis DNA in $30 \mathrm{~min}$, with lower limits of detection of 50 or 100 copies $\left(2 \times 10^{3}\right.$ or $4 \times 10^{3}$ copies $\mathrm{ml}^{-1}$ ) of template DNA using a LightCycler or by visual detection, respectively.

Fig. 2 shows the results of real-time fluorescence detection using a LightCycler. DNA amplification is indicated by the rising curve of fluorescence in Fig. 2(a). With the LAMP assay, it was possible to detect 100 copies per tube $\left(4 \times 10^{3}\right.$ copies $\mathrm{ml}^{-1}$ ), with the curve beginning to rise at $12-$ $13 \mathrm{~min}$ and reaching a plateau at $22-23 \mathrm{~min}$. Detection of 50 copies per tube $\left(2 \times 10^{3}\right.$ copies $\left.\mathrm{ml}^{-1}\right)$ could be achieved in $30 \mathrm{~min}$. In reactions of 10 copies per tube $\left(4 \times 10^{2}\right.$ copies $\mathrm{ml}^{-1}$ ), products were detected in two out of three tubes, with no product detected in the remaining tube.

On visual detection, the results were judged at a reaction time of $30 \mathrm{~min}$. By both visually determined turbidity and fluorescence detection, the assays could detect 100 copies of the target sequence per tube $\left(4 \times 10^{3}\right.$ copies $\left.\mathrm{ml}^{-1}\right)$. However, the results were unstable at concentrations below 50 copies per tube $\left(2 \times 10^{3}\right.$ copies $\left.\mathrm{ml}^{-1}\right)$. Fig. 3 shows the results of visual fluorescence detection (Fig. 3a) and turbidity detection (Fig. 3b). 
Table 3. Clinical information on specimens collected from non-PCP patients

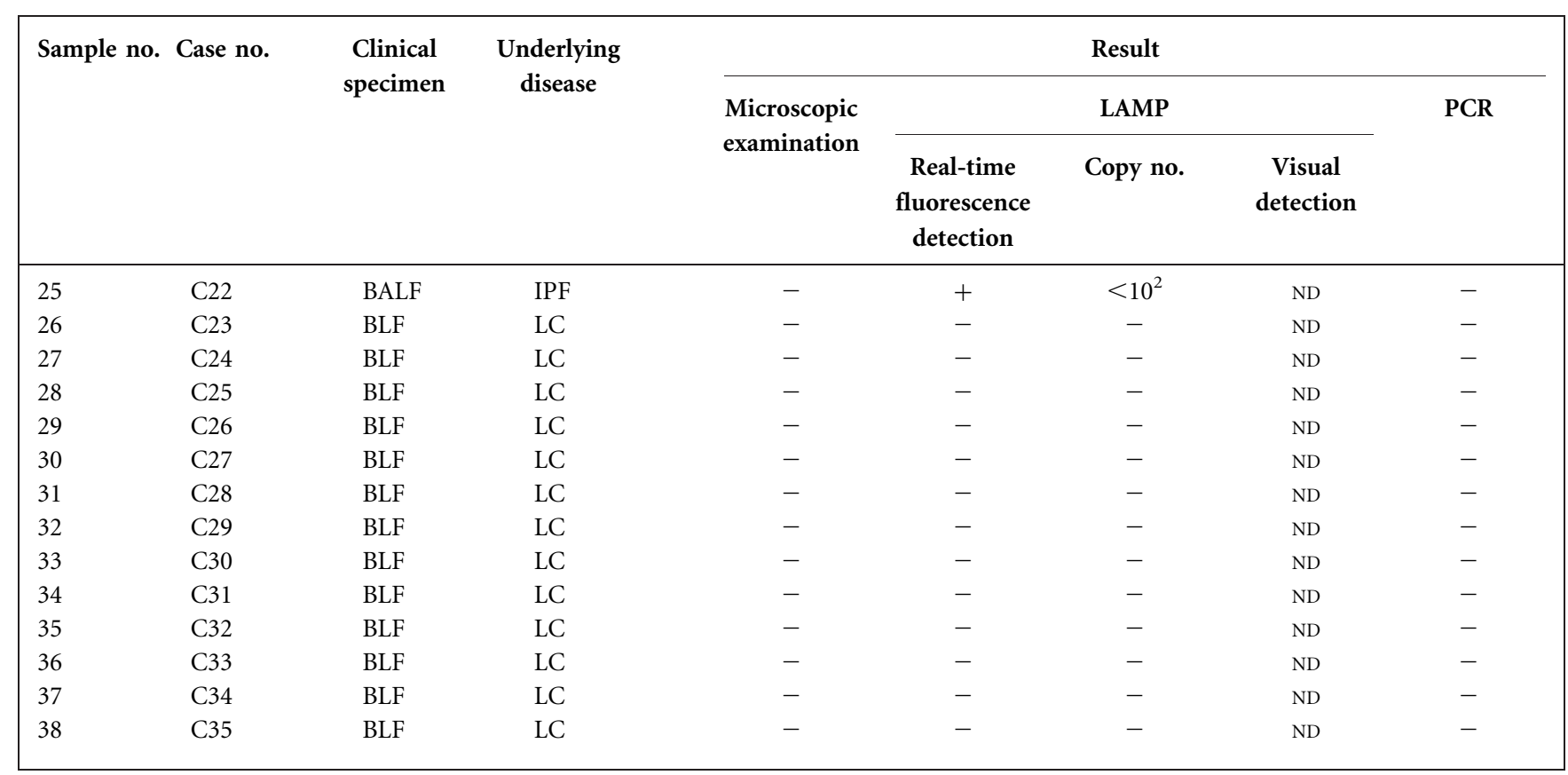

IPF, Idiopathic pulmonary fibrosis; LC, lung cancer; ND, not determined.

\section{Quantitative capability}

The times to when fluorescence started rising and when it reached a plateau were short when there were high gene copy numbers in the tube. The graphs for each of the triplicate samples showed good accordance between $P$. jirovecii plasmid copy numbers of $2 \times 10^{6}$ to 100 per tube $\left(8 \times 10^{7}\right.$ to $4 \times 10^{3}$ copies $\left.\mathrm{ml}^{-1}\right)$ (Fig. $\left.2 \mathrm{a}\right)$. However, there was no quantitative capability at template DNA copy numbers of less than 100 per tube $\left(4 \times 10^{3}\right.$ copies $\left.\mathrm{ml}^{-1}\right)$.

\section{Melting-curve analysis}

As shown in Fig. 2(b), the melting curves of each sample were almost identical. This assay did not show a nonspecific reaction within $30 \mathrm{~min}$; however, the reaction of some templates present at less than 10 copies per tube $(400$ copies $\mathrm{ml}^{-1}$ ) for more than $30 \mathrm{~min}$ yielded melting-curve peaks that were different from those seen in the specific reactions. Non-specific reactions were observed using clinical specimens when the assay was continued for $1 \mathrm{~h}$. However, the melting-curve peaks of non-specific reactions could be distinguished from those of specific reactions (Fig. 4). Fig. 4 shows examples of the results of LAMP assays of PCP patients using a LightCycler. The melting curve of sample 12 gave a similar result to the positive control. One of the two distilled water samples and sample 13 showed non-specific reactions, and the peaks of their melting curves were different from those of the positive control.

In this study, we used melting-curve analysis rather than electrophoresis to distinguish specific LAMP products, as the process of agarose gel electrophoresis tends to cause severe contamination. There have been several recent reports of melting-curve analysis of PCR products $(\mathrm{Bu}$ et al., 2005; Haverstick et al., 2004; Shrestha et al., 2003). PCR products can be characterized by melting-curve analysis because each double-stranded DNA molecule has a specific melting temperature $\left(T_{\mathrm{m}}\right)$ at which $50 \%$ of the DNA becomes single-stranded. The $T_{\mathrm{m}}$ value is dependent on

Table 4. Sequences of the LAMP primers used in this study

\begin{tabular}{|ll|}
\hline Primer & \multicolumn{1}{c|}{ Sequence $\left(\mathbf{5}^{\prime} \rightarrow \mathbf{3}^{\prime}\right)$} \\
\hline F3 & AGCGTATATTAAAGTTGCTGC \\
B3 & GCTTTGAACACTCTAATTTCTCA \\
FIP & CCAGTGCACACACTTCGGAGTTAAAAAGCTCGTAGTTGAACCTA \\
BIP & GCGATCCTTCCTTCTGGATTACAAGTAAAAGGCCCTGGTTA \\
FL & GACCGGGCCGTCAAC \\
BL & GTATGCCCTTCATTGGGTGTAT \\
\hline
\end{tabular}




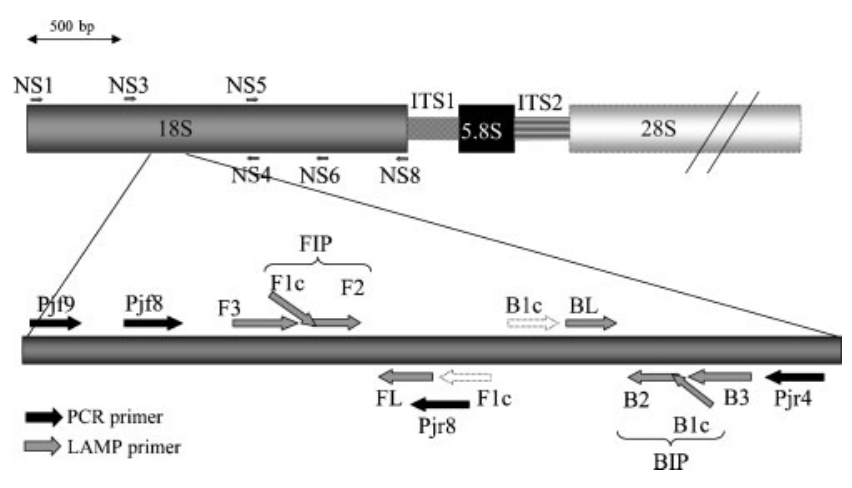

Fig. 1. Map showing the location of primers on the $18 \mathrm{~S}$ rRNA gene of $P$. jirovecii. ITS, Internal transcribed spacer.

both base sequence and GC content. Amplification of primer-dimers or non-specific products will be observed as peaks with different $T_{\mathrm{m}}$ values. $\mathrm{Bu}$ et al. (2005) reported identification of PCR products amplified from Candida spp. and Aspergillus spp. using melting-curve analysis, and specific probes have been applied to melting-curve analysis typing of hepatitis virus (Haverstick et al., 2004) and differentiation of Mycobacterium species (Shrestha et al., 2003). This is believed to be the first report of meltingcurve analysis of LAMP products. Identification of LAMP products may theoretically be determined by probes. However, as a relatively large number of oligonucleotides are already used, this would add to the complexity of this assay.

\section{Clinical samples}

A total of 22 samples (21 from PCP patients and 1 from a non-PCP subject) tested positive in the LAMP assay using the LightCycler (Tables 2 and 3). The diagnostic sensitivity of this assay was $87.5 \%$ (21/24 PCP cases). In comparison, $P$. jirovecii DNA was detected in only 17 samples from PCP patients by nested PCR. The nested PCR used in the present study could detect 100 copies of plasmid per tube $\left(10^{3}\right.$ copies $\mathrm{ml}^{-1}$ ) (data not shown) and the sensitivity of this method was 20 times lower than a quantitative realtime PCR reported by Brancart et al. (2005). However, this nested PCR did not detect target DNA in any specimens from non-PCP cases or LAMP reaction-negative specimens. With regard to quantitative capability, we speculated that the target DNA copy number in sample 12 in Fig. 4(a) was equivalent to less than 100 copies per tube $\left(4 \times 10^{3}\right.$ copies $\left.\mathrm{ml}^{-1}\right)$. Similarly, clinical samples were examined with control plasmid $\left(10^{2}, 10^{4}\right.$ and $10^{6}$ copies per tube, i.e. $4 \times 10^{3}, 4 \times 10^{5}$ and $4 \times 10^{7}$ copies $\mathrm{ml}^{-1}$, respectively) each time, and we estimated the equivalent DNA copy numbers of clinical specimens, as shown in Table 2.

Only one patient (case 22) in the present study showed colonization with $P$. jirovecii. There have been a number of recent reports of $P$. jirovecii colonization in both the general population and in patients with respiratory disease (Maskell et al., 2003; Medrano et al., 2005; Vidal et al., 2006), with colonization rates of about $20 \%$ in healthy subjects (Medrano et al., 2005) and about $30 \%$ in patients with interstitial lung disease (Vidal et al., 2006). Further evaluation of this LAMP method with larger numbers of clinical specimens is currently under way in our laboratory.
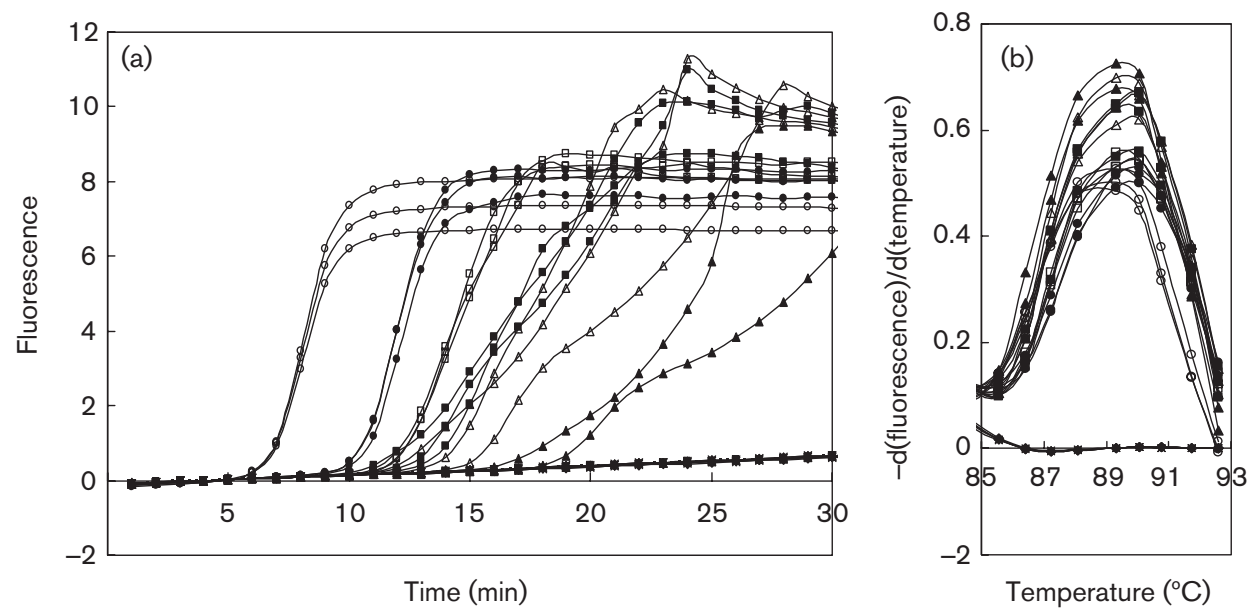

Fig. 2. Sensitivity of the LAMP assay. Triplicate samples of serial dilutions of $P$. jirovecii plasmid solution were used as DNA template. LAMP products were amplified and analysed using a LightCycler. (a) Amplification analysis is shown, where the rising curves of fluorescence indicate DNA amplification. (b) In the melting-curve analysis, the melting temperature of each sample is shown as a peak. Number of $P$. jirovecii plasmid copies: $\bigcirc, 2 \times 10^{6}$ copies $\left(8 \times 10^{7}\right.$ copies $\left.\mathrm{ml}^{-1}\right) ; \bullet, 10^{4}$ copies $\left(4 \times 10^{5}\right.$ copies

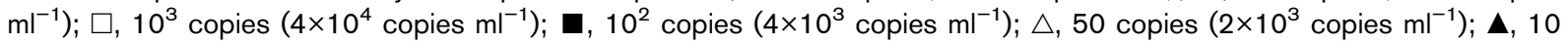
copies $\left(4 \times 10^{2}\right.$ copies $\left.\mathrm{ml}^{-1}\right) ; \square, 1$ copy $\left(40\right.$ copies $\left.\mathrm{ml}^{-1}\right)$; distilled water. 
(a)
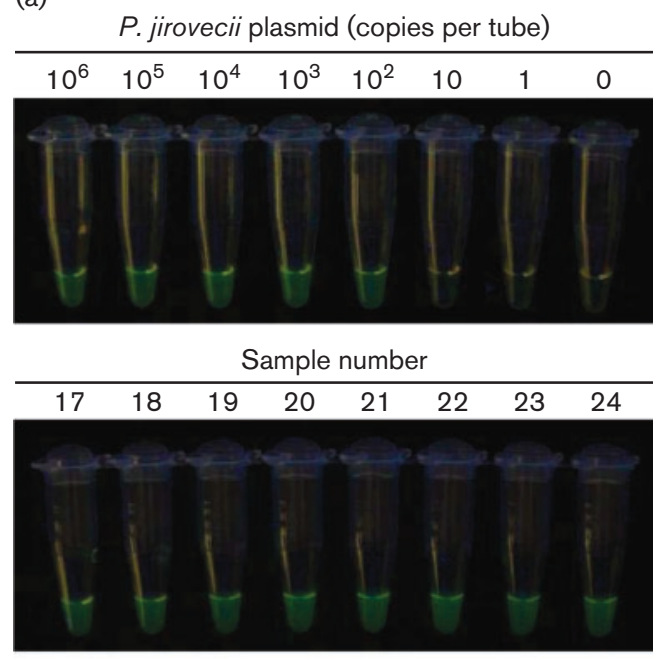

(b)

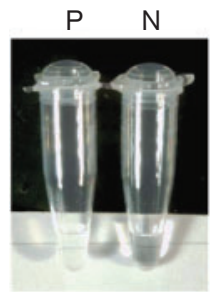

Fig. 3. Visual detection of LAMP products. (a) For fluorescence detection, the upper panel shows DNA templates used at $1-10^{6}$ copies $\left(40-4 \times 10^{7}\right.$ copies $\left.\mathrm{ml}^{-1}\right)$ of $P$. jirovecii plasmid, and the lower panel shows clinical samples. (b) Examples of positive $(P)$ and negative $(\mathrm{N})$ controls for turbidity detection are shown.

\section{Cost of the LAMP reaction}

The LAMP reaction cost about $€ 2.70$ per test. Inclusion of the fluorescence detection reagent increased the cost to $€ 3.20$ per test. The costs were about the same as those of the PCR method. The LAMP method will be cheaper than the PCR method if visual detection without special equipment is used.

\section{DNA extraction}

In this study, we used a NucliSENS kit (bioMérieux) for extraction of $P$. jirovecii DNA, as described by Fischer et al. (2001) and Larsen et al. (2002). This was completed in 1$2 \mathrm{~h}$, generally with satisfactory results. However, simpler and easier methods of DNA extraction are necessary for clinical on-site application of this LAMP system. DNA extraction using this kit cost $€ 4.50$ per sample.

A method for extraction of $P$. jirovecii DNA using an FTA card (Whatman) has been reported (Jaijakul et al., 2005). We attempted the LAMP assay with FTA cards for some specimens, but the results were not consistent (data not shown).

\section{Advantage of the LAMP method}

Visual detection is possible with the LAMP method (Fig. 3a). A sensitive real-time PCR method capable of detecting 50 copies of target sequence $\mathrm{ml}^{-1}$ has been developed (Brancart et al., 2005), although this system requires the use of specialized equipment. In contrast, amplification and visual detection of the LAMP reaction with a conventional incubator is a simple identification
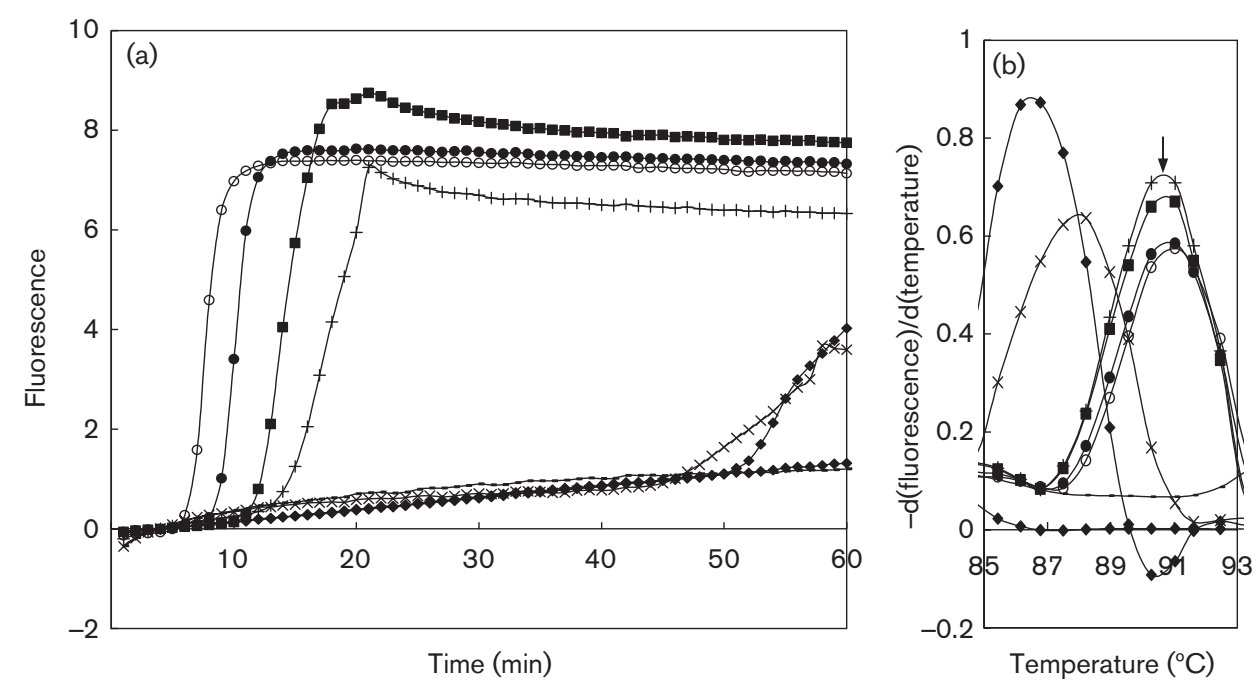

Fig. 4. Examples of clinical samples (PCP group) in the LAMP assay using a LightCycler: (a) amplification analysis, (b) meltingcurve analysis. The arrow in (b) indicates the specific peak. -, Sample 11 (negative reaction); + , sample 12 (positive reaction); $\times$, sample 13 (negative with non-specific reaction). Positive controls: $\bigcirc$, P. jirovecii plasmid DNA $10^{6}$ copies $\left(4 \times 10^{7}\right.$ copies $\left.\mathrm{ml}^{-1}\right) ; \bullet, 10^{4}$ copies $\left(4 \times 10^{5}\right.$ copies $\left.\mathrm{ml}^{-1}\right) ; \mathbf{\square}, 10^{2}$ copies $\left(4 \times 10^{3}\right.$ copies $\left.\mathrm{ml}^{-1}\right)$. Negative control: $\diamond$, distilled water. 
method, although its sensitivity is slightly lower than that of the real-time PCR-based method. In patients with suspected PCP, this LAMP method is competent to diagnose PCP. Therefore, visual detection of the LAMP reaction is faster and easier than the PCR-based method and may be applied in general clinical laboratories.

\section{ACKNOWLEDGEMENTS}

This study was partly supported by Health Science Research Grants for Research on Emerging and Re-emerging Infectious Disease from the Ministry of Health, Labour and Welfare of Japan (to K. M.).

\section{REFERENCES}

Brancart, F., Rodriguez-Villalobos, H., Fonteyne, P. A., Peres-Bota, D. \& Liesnard, C. (2005). Quantitative TaqMan PCR for detection of Pneumocystis jiroveci. J Microbiol Methods 61, 381-387.

Bu, R., Sathiapalan, R. K., Ibrahim, M. M., Al-Mohsen, I., Almodavar, E., Gutierrez, M. I. \& Bhatia, K. (2005). Monochrome LightCycler PCR assay for detection and quantification of five common species of Candida and Aspergillus. J Med Microbiol 54, 243-248.

Cenis, J. L. (1992). Rapid extraction of fungal DNA for PCR amplification. Nucleic Acids Res 20, 2380.

Endo, S., Komori, T., Ricci, G., Sano, A., Yokoyama, K., Ohori, A., Kamei, K., Franco, M., Miyaji, M. \& Nishimura, K. (2004). Detection of gp43 of Paracoccidioides brasiliensis by the loop-mediated isothermal amplification (LAMP) method. FEMS Microbiol Lett 234, 93-97.

Fischer, S., Gill, V. J., Kovacs, J., Miele, P., Keary, J., Silcott, V., Huang, S., Borio, L., Stock, F. \& other authors (2001). The use of oral washes to diagnose Pneumocystis carinii pneumonia: a blinded prospective study using a polymerase chain reaction-based detection system. J Infect Dis 184, 1485-1488.

Flori, P., Bellete, B., Durand, F., Raberin, H., Cazorla, C., Hafid, J., Lucht, F. \& Sung, R. T. (2004). Comparison between real-time PCR, conventional PCR and different staining techniques for diagnosing Pneumocystis jiroveci pneumonia from bronchoalveolar lavage specimens. J Med Microbiol 53, 603-607.

Frenkel, J. K. (1999). Pneumocystis pneumonia, an immunodeficiency-dependent disease (IDD): a critical historical overview. J Eukaryot Microbiol 46, 89S-92S.

Haverstick, D. M., Bullock, G. C. \& Bruns, D. E. (2004). Genotyping of hepatitis $\mathrm{C}$ virus by melting curve analysis: analytical characteristics and performance. Clin Chem 50, 2405-2407.

Helweg-Larsen, J., Tsolaki, A. G., Miller, R. F., Lundgren, B. \& Wakefield, A. E. (1998). Clusters of Pneumocystis carinii pneumonia: analysis of person-to-person transmission by genotyping. QJM 91, 813-820.

Hocker, B., Wendt, C., Nahimana, A., Tonshoff, B. \& Hauser, P. M. (2005). Molecular evidence of Pneumocystis transmission in pediatric transplant unit. Emerg Infect Dis 11, 330-332.

Iwamoto, T., Sonobe, T. \& Hayashi, K. (2003). Loop-mediated isothermal amplification for direct detection of Mycobacterium tuberculosis complex, M. avium, and $M$. intracellulare in sputum samples. J Clin Microbiol 41, 2616-2622.

Jaijakul, S., Saksirisampant, W., Prownebon, J., Yenthakam, S., Mungthin, M., Leelayoova, S. \& Nuchprayoon, S. (2005).
Pneumocystis jiroveci in HIV/AIDS patients: detection by FTA filter paper together with PCR in noninvasive induced sputum specimens. J Med Assoc Thai 88, S294-S299.

Larsen, H. H., Masur, H., Kovacs, J. A., Gill, V. J., Silcott, V. A., Kogulan, P., Maenza, J., Smith, M., Lucey, D. R. \& Fischer, S. H. (2002). Development and evaluation of a quantitative, touch-down, real-time PCR assay for diagnosing Pneumocystis carinii pneumonia. J Clin Microbiol 40, 490-494.

Makimura, K., Murayama, S. Y. \& Yamaguchi, H. (1994). Detection of a wide range of medically important fungi by the polymerase chain reaction. J Med Microbiol 40, 358-364.

Maskell, N. A., Waine, D. J., Lindley, A., Pepperell, J. C., Wakefield, A. E., Miller, R. F. \& Davies, R. J. (2003). Asymptomatic carriage of Pneumocystis jiroveci in subjects undergoing bronchoscopy: a prospective study. Thorax 58, 594-597.

Medrano, F. J., Montes-Cano, M., Conde, M., de la Horra, C., Respaldiza, N., Gasch, A., Perez-Lozano, M. J., Varela, J. M. \& Calderon, E. J. (2005). Pneumocystis jirovecii in general population. Emerg Infect Dis 11, 245-250.

Mori, Y., Nagamine, K., Tomita, N. \& Notomi, T. (2001). Detection of loop mediated isothermal amplification reaction by turbidity derived from magnesium pyrophosphate formation. Biochem Biophys Res Commun 289, 150-154.

Nagamine, K., Hase, T. \& Notomi, T. (2002). Accelerated reaction by loop-mediated isothermal amplification using loop primers. Mol Cell Probes 16, 223-229.

Notomi, T., Okayama, H., Masubuchi, H., Yonekawa, T., Watanabe, K., Amino, N. \& Hase, T. (2000). Loop-mediated isothermal amplification of DNA. Nucleic Acids Res 28, E63.

Poon, L. L., Leung, C. S., Chan, K. H., Lee, J. H., Yuen, K. Y., Guan, Y. \& Peiris, J. S. (2005). Detection of human influenza A viruses by loop-mediated isothermal amplification. J Clin Microbiol 43, 427-430.

Poon, L. L., Wong, B. W., Ma, E. H., Chan, K. H., Chow, L. M., Abeyewickreme, W., Tangpukdee, N., Yuen, K. Y., Guan, Y. \& other authors (2006). Sensitive and inexpensive molecular test for falciparum malaria: detecting Plasmodium falciparum DNA directly from heat-treated blood by loop-mediated isothermal amplification. Clin Chem 52, 303-306.

Shah, J. S., Pieciak, W., Liu, J., Buharin, A. \& Lane, D. J. (1996). Diversity of host species and strains of Pneumocystis carinii is based on rRNA sequences. Clin Diagn Lab Immunol 3, 119-127.

Shrestha, N. K., Tuohy, M. J., Hall, G. S., Reischl, U., Gordon, S. M. \& Procop, G. W. (2003). Detection and differentiation of Mycobacterium tuberculosis and nontuberculous mycobacterial isolates by real-time PCR. J Clin Microbiol 41, 5121-5126.

Stringer, J. R., Beard, C. B., Miller, R. F. \& Wakefield, A. E. (2002). A new name (Pneumocystis jirovecii) for pneumocystis from humans. Emerg Infect Dis 8, 891-896.

Vidal, S., de la Horra, C., Martin, J., Montes-Cano, M. A., Rodriguez, E., Respaldiza, N., Rodriguez, F., Varela, J. M., Medrano, F. J. \& other authors (2006). Pneumocystis jirovecii colonisation in patients with interstitial lung disease. Clin Microbiol Infect 12, 231-235.

White, T. J., Bruns, T., Lee, S. \& Taylor, J. (1990). Amplification and direct sequencing of fungal ribosomal RNA genes for phylogenetics. In PCR Protocols: a Guide to Methods and Applications, pp. 315-322. Edited by M. A. Innis, D. H. Gelfand, J. J. Sninsky \& T. J. White. San Diego, CA: Academic Press. 